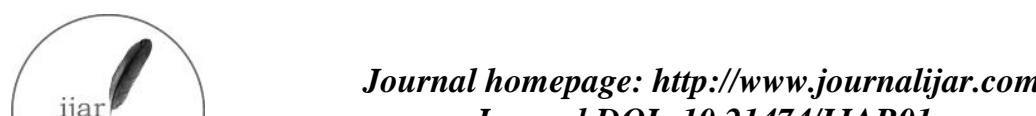 Journal DOI: 10.21474/IJAR01 INTERNATIONAL JOURNAL $2=$ ISSN NO. 2320-5407 \\ RESEARCH ARTICLE
}

\section{THE ANALYSIS OF FACTORS AFFECTING THE EFFECTIVENESS OF POLICY OF RESORT ISLANDS IN THOUSAND ISLANDS ADMINISTRATIVE DISTRICT.}

\author{
EkoSugiyanto \\ Lecturer of Nasional University, Jakarta.
}

\section{Manuscript Info \\ Manuscript History:}

Received: 18 February 2016

Final Accepted: 29 March 2016

Published Online: April 2016

Key words:

Policy Effectiveness of Resort Islands in Thousand Islands Administrative District, Environmental Characteristics, Characteristics of Workers, Characteristics of Policy and Management Practice.

*Corresponding Author

EkoSugiyanto.

\begin{abstract}
The local government has an important role in managing and coordinating with related parties about the policy of resort islands in Thousand Islands Administrative District. This district has heterogeneous human resources with heterogeneous characteristics as well, leading to different perception of their contribution in the policy making. It can lead to a problem regarding the effectiveness of the policy. Therefore, to find out the extent to which the expectation of the society is fulfilled by the local government, it is necessary to conduct a study on the Analysis of Policy Effectiveness of Resort Islands in Thousand Islands Administrative District Observed from the Characteristics of Employees in Thousand Islands Administrative District. This study focuses on the analysis of Policy Effectiveness of Resort Islands in Thousand Islands Administrative District, observed from the characteristics of Stakeholders in the process of policy formulation by the employees in Thousand Islands Administrative District. Due to limited time, cost and effort, the author limits this study on one independent variable and four factors. The four factors that will be discussed in this study are Organizational Characteristics (F1), Environmental Characteristics (F2), Characteristics of Workers (F3), Characteristics of Policy and Management Practice (F4), and Policy Effectiveness of Resort Islands in Thousand Islands Administrative District.
\end{abstract}

Copy Right, IJAR, 2016,. All rights reserved.

\section{Introduction:-}

Thousand Islands National Park is a marine conservation area in Indonesia, located approximately $45 \mathrm{~km}$ to the north of Jakarta's coast with geographical location of $5^{\circ} 23^{\prime}-5^{\circ} 40^{\prime} \mathrm{S}, 106^{\circ} 25^{\prime}-106^{\circ} 37^{\prime}$ E. Administratively, this national park is located in Thousand Islands Administrative District, in North Thousand Islands Sub-District, in three Administrative Villages of Panggang Island, Kalapa Island, and Harapan Island. Geographically, this national park is located at $5^{\circ} 24^{\prime}-5^{\circ} 45^{\prime} \mathrm{S}, 106^{\circ} 25^{\prime}-106^{\circ} 40^{\prime} \mathrm{E}$, covering 107,489 ha of water area (the Decree of the Minister of Forestry No 6310/Kpts-II/2002, approximately 22,65\% of the district's water area) and 39.50 ha of land area (West Penjaliaran Island and East Penjaliran Island). Thus, the other 108 islands are not included in Thousand Islands National Park.

According to research finding by Sutiman, Thousand Islands District is formed with the Government Regulation (PP) No. 55 Year 2001 and the Decree (SK) by the Governor of DKI Jakarta No 186 Year 2000 regarding the establishment of the administrative village in the Thousand Islands. The establishment of Thousand Islands from a sub-district into a district means that the local government should be able to finance a variety of facilities and infrastructures as well as human resources to support public services. The natural resources of Thousand Islands provide opportunities for the tourism sector and marine fisheries. Commodities developed are seaweeds and groupers by 460 farmers. The production of marine fisheries reached 57.2 million kilograms with a value of IDR 97.26 billion in 2000, that was decreasing compared to 1999 that reached 63 million tons. Despite the quite large production, the fishing community remains poor. 
Based on the available data, the factors affecting the level of poverty is the low quality of human resources, traditional fishing gear, the lack of basic facilities and infrastructure (transportation/ship/motorboat, education, health), fish auction (TPI), marine pollution, high living cost (needs to be proved by a comprehensive research), and the existing policies. Generally, the policies are Top Down policies, born from strategic management approach, while the community is passive and takes everything for granted. Referring to the development of tourism rate and data described by Sutiman, it is necessary to review whether the existing policies applied in Thousand Islands are effective or not, hampered by the human resources, as well as natural factors.

\section{Research method:-}

This research applies a case study through a quantitative approach. The researcher also conducts field observation as well as literature study from the printed, electronic and online media. To validate the data, the study applies the technique of triangulation; a technique to examine the validity of the data obtained from one source by comparing it to other sources in different time, or comparing the data obtained from one source by using different methods.

\section{Theoretical concept:-}

\section{Effectiveness:-}

Steers (1985:87) states that "Effectiveness is a range of effort of a program as a system with limited resources and particular facilities to meet the targeted objectives without immobilizing the means and resources and putting unreasonable pressure towards its implementation".

According to Ravianto (1989: 113), effectiveness is how well the work is carried out, the extent to which people produce expected output is. It means that the job is effective if it can be completed according to the plan, in terms of time, cost and quality. Ndraha (2005:163) states that effectiveness is used to measure progress, in order to measure the success in achieving objectives. In regard to governmental effectiveness, Ndraha (2005:163) argues:

Effectiveness is defined abstractly as the level of objective's achievement, measured according to the formula of results divided by (per) purposes. The objective originated from abstract vision can be deduced to be concrete objective or strategy. Strategy is measurable objective, concept of relative result, depending on the question, the chain of which in the process and governance cycle the result is defined. Is it in the output point? Outcome?Feedback? Who defines it: the government, the governed people, or together?

According to Sedarmayanti, (2001: 59). "Effectiveness is a measure that gives an idea of how far the target can be achieved. The definition is more oriented to the output than the input. If efficiency is associated with the effectiveness, the increase of effectiveness does not necessarily increase efficiency".

According to Devung, effectiveness is a level of ability to achieve the objectives in appropriate and good manner (Devung, 1988: 25).

According to the dictionary of Administration Management, effectiveness comes from the word effective that means the occurrence of a desired effect in an act (1981:24).

\section{Policy:-}

According to Friedrich (1969) in Agustino (2008:7), public policy is a series of actions/activities proposed by an individual, group, or government in a particular environment where there are obstacles (difficulties) and possibilities (opportunities) where the policy is proposed to overcome them to reach the desired objective.

In connection with the policy, Anderson (1984) in Agustino (2008:7) defines the policy as follows: A series of activities that have specific purpose followed and implemented by an actor or group of actors associated with a problem or a considered thing.

According to Harold Lasswell and Abraham Kaplan in the book of public policy implementation and the professional ethics of the civil service: "Policy is formulated as aa projected program of goals, values and practices" Setyoko (2008: 19). 
According to Wilian N. Dunn (2003:44), policy is "An intellectual and practical activity aimed at creating, critically evaluating, and communicating knowledge about and within the policy process".

From aforementioned definitions, policy can be defined as a decision made by an individual, group or government aimed at a group with a specific purpose,

\section{Thousand Islands Marine National Park:-}

Thousand Islands is specified to be the Marine National Park with the Decree of the Minister of Forestry No. 162/Kpts-II/1995 and No. 6310/Kpts-II/2002, managed by the Office of the Thousand Islands Marine National Park, the Department of Forestry. The area covers 107,489 hectares with approximately 44 islands. The islands located in this marine national park are ideal spots for snorkeling, swimming, or diving.

Thousand Islands have islands designated as islands of nature conservation, such as Rambut Island and Onrust Island that are designated as the islands of cultural heritage.

\section{Resort Islands in Thousand Islands:-}

a. Kahyangan Island

This island is also called Cipir or Kuipir Island. This island is one of the islands in UntungJawa Administrative Village that has been organized for tourist destination. The island has some historical relics, one of which is a fort built by the Dutch in the VOC era. The island has a clear and clean source of freshwater. Kahyangan Island can be reached by motorboat provided to sail the round-trip route to Marina Beach, Ancol, and Kahyangan Island.

\section{b. Pabelokan Island}

Pabelokan Island is the only island in Thousand Islands that is always busy with business activities. This island has officebuildings, dormitories, docks, power plants, water purification and helipad. The island is used as a sort of base camp by Pertamina, or an offshore oil base with various supporting facilities. In 1970, the source of oil is discovered off the coast of the island. Today, the rig is prepared to supply oil to a tanker with a computerized system.Pabelokan Island consists of 27 hectares of coral clusters.

\section{c. Bidadari Island}

Manado-style floating cottage is a hallmark of this nearest resort island to Marina Ancol (20 minutes by speedboat). On this island lies the ruin of the Dutch fort named Martello Tower. The island is also called Sakit Island.

\section{d. Onrust Island}

Onrust Island is also called Ship Island. Onrust in Dutch means agitated, or unrest. In Dutch colonial time, the island always looked busy day and night. Therefore, most residents of UbiBesar and UntungJawa Island refer to it as Busy Island. The island is only about 12 hectares, yet it records a long history.

\section{e. Ayer Island}

Ayer Island is nicknamed as the Pearl Islands. It covers less than ten hectares, is near to the Marina Beach, Ancol and can be reached in 30 minutes by boat. The island has welcomed visitors since 1950. During his lifetime, former President Sukarno made this island his resting resort. Former President Sukarno had also invited Former President Tito of Yugoslavia and Former UN Secretary General, U Nu, to visit this island. Papua-style floating cottage is the pride of this resort island that is only $14 \mathrm{~km}$ (30 minutes) from Marina Ancol.

\section{f. Puteri Island}

Puteri Island is located on the north side of Thousand Islands. Because of its far distance from Jakarta, people reach it practically by plane. A flight is available from Kemayoran to Panjang Island located near to Puteri Island. From Panjang Island, the trip is continued by a motorboat to Puteri Island. This island is isolated from the other islands. It has beautiful white sandy beaches.

\section{g. Matahari Island}

The island is closed for renovation ${ }^{[3]}$. It has a two-storey cottage with luxurious rooms and water sports and fishing facilities. Matahari Island has a helipad for resort guests who arrive by helicopter. 


\section{h. SepaIslan}

Sepa Island has white sandy beach, clear sea water, and gently sloping beach. This island is a training ground for novice divers to get open water certificate. The island is located about one and a half hour from Marina Ancol and known as an ideal spot for swimming, diving, snorkeling, or fishing. Water sports facilities and diving equipment rental are available in this island.

\section{i. West and East Pantara Islands}

Both islands are known as the ideal places for diving and snorkeling. The islands are located about 2 hours from Marina Ancol and they were formerly known as the Ghost Islands. The development of these islands had been carried out by Japanese airlines.

\section{j. $\quad$ Bira Island}

Bira Island has 9-hole golf course, swimming pool, bikes to get around the island, children's playground and a fishing spot. The island is $100 \mathrm{~km}$ away from Marina Ancol.

\section{k. Kotok Island}

Kotok Island is an example of a tropical atoll island with pristine vegetation, crystal-clear seas and colorful rock formations so it becomes the main destination for divers. The island is also a conservation place for Brahminy Kite, the mascot of Jakarta Province.

\section{Pelangi Island}

Pelangi Island is located in the same cluster with Puteri, Petondan, Sepa and Melinjo Island. This island was established in 1990 as one of the resorts in Thousand Islands.

\section{m. Papa Theo Island}

Papa Theo Island or East Pebondan Island is located in the same cluster with Kelor and Kelapa Island. It covers eight hectares, and is $108 \mathrm{~km}$ away from Marina Beach, Ancol. The name is given to the island by a call sign of radio among residents.

\section{n. Laki Island}

Laki Island is a marine tourism resort opened in 1988 and is always crowded. LakiBesar and Laki Kecil Islands are nearby. Laki Island covers about 30 hectares. Riding a motorboat from Mauk Beach, Sepatan, is a practical way to get to this island.

\section{o. Pamagaran Island}

The island covers about 16 hectares with a ring of coral reefs widened as far as one kilometer into the sea surrounding the island. The length is about 1.7 kilometers. The widest part is about 300 meters while the narrowest is about 40 meters.

\section{p. Sabira Island}

Sabira Island is called NoordWachter by the Ducth, meaning the north guardian. The name is given due to the fact that Sabira Island is the northernmost island among other islands in Thousand Islands.

\section{q. Saktu and Penike Island}

It is 81 kilometers away from Ancol Beach. It takes three hours to reach it from TanjungPriok. Saktu Island has stunning scenery, surrounded by white sandy beaches with typical palm trees and lagoons of tropical areas. The island has a lighthouse built by an expert from Indonesia in 1981. The lighthouse was constructed of steel with a height of 60 meters.

\section{Factors affecting the effectiveness of the policy:-}

There are four factors affecting the effectiveness of the policy:

\section{Organizational Characteristic:-}

Organizational characteristic consists of organizational structure and technology that may affect certain aspects of the effectiveness in various manners. Structure means a relationship with relatively precise nature, such as found in 
the organization. In connection with the composition of human resources, structure includes how an organization prepares its human resources in completing the work.

\author{
Technology means the mechanism of an organization to transform raw inputs into outputs:- \\ Organizational Characteristic $\left(\mathrm{F}_{1}\right)$ \\ * Objectives-oriented, \\ * People-oriented, \\ * Structure-oriented, \\ * System-and-procedure-oriented
}

\title{
Environmental Characteristic:-
}

Internal and external environment also affect the effectiveness. The success of the organizational relationship seems very dependent on the level of the key variable, that is, the level of predictability of the environmental condition, the accuracy of perceptions on the environmental condition, and the level of organizational rationalism. All three factors affect the accuracy of organization in response to environmental changes.

Environmental Characteristic $\left(\mathrm{F}_{2}\right)$

* Very conducive working environment.

* Conducive working environment.

* Less conducive working environment.

* Non conducive working environment.

\section{Characteristics of Workers:-}

In fact, the members of the organization are the most important influential factor because their behavior in the long term will facilitate or hinder the achievement of organizational objectives. Workers are resources that directly relate to the management of all the resources that exist within the organization, therefore their behavior affects the achievement of organizational objectives. Workers are the main asset in the organization that will greatly affect the effectiveness. Even advanced technology supported by a good structure will be no use without workers.

Characteristics of Workers $\left(\mathrm{F}_{3}\right)$

* Period of Employment more than 15 years.

* Period of Employment between 10 to 14 years.

* Period of Employment between 6 to 9 years.

* Period of Employment less than 5 years.

Characteristics of Policy and Management Practice:-

The increase of technological complexity and environmental development leads to the increase of the difficulty of management in coordinating people and process for successful organizations.

Characteristics of Policy and ManagementPractice $\left(\mathrm{F}_{4}\right)$

* Feeling of getting quite fair treatment.

* Feeling of getting fair treatment.

* Feeling of getting less fair treatment.

* Feeling of getting unfair treatment.

\section{Discussion:-}

The Analysis of Differences in the Perception of Employees of Resort Islands in Thousand Islands Administrative District regarding the Analysis of Policy Effectiveness Observed from the Characteristics of Employees based on Organizational Characteristics: there are significant differences. The mean of the employees with structure-oriented organizational characteristics is 74.04. They tend to feel that their Effectiveness of Role is more effective compared to the employees with people-oriented organizational characteristics with mean of 66.80 . The mean of the employees with objective-oriented organizational characteristics is 67.00 , while the mean of the employees with system-and-procedure-oriented organizational characteristics is 68.35 , with the level of confidence of $95 \%$. Despite the relative small comparison figures, in population these comparisons are significant enough to be used as consideration for decision making.

The Analysis of Differences in the Perception of Employees of Resort Islands in Thousand Islands Administrative District regarding the Analysis of Policy Effectiveness Observed from the Characteristics of Employees based on Environmental Characteristics: there are significant differences. The mean of the employees who feel conducive 
working environment is 77.50. They tend to feel that their Effectiveness of Role is more effective compared to the employees who feel very conducive working environment with mean of 69.62. The mean of the employees who feel less conducive working environment is 66.35 , while the mean of the employees who feel non conducive working environment is 75.00 , with the level of confidence of $95 \%$. Despite the relative small comparison figures, in population these comparisons are significant enough to be used as consideration for decision making.

The Analysis of Differences in the Perception of Employees of Resort Islands in Thousand Islands Administrative District regarding the Analysis of Policy Effectiveness Observed from the Characteristics of Employees based on Characteristics of Workers: there are significant differences. The mean of the employees with Period of Employment more than 15 years is 71.43 . They tend to feel that their Effectiveness of Role is more effective compared to the employees with Period of Employment less than 5 years with mean of 70.17. The mean of the employees with Period of Employment between 10 to 14 years is 61.58 , while the mean of the employees with Period of Employment between 6 to 9 years is 70.17, with the level of confidence of 95\%. Despite the relative small comparison figures, in population these comparisons are significant enough to be used as consideration for decision making.

The Analysis of Differences in the Perception of Employees of Resort Islands in Thousand Islands Administrative District regarding the Analysis of Policy Effectiveness Observed from the Characteristics of Employees based on Characteristics of Policy and Management Practice: there are significant differences. The mean of the employees who feel getting fair treatment is 73.78. They tend to feel that their Effectiveness of Role is more effective compared to the employees who feel getting quite fair treatment with mean of 68.72 . The mean of the employees who feel getting less fair treatment is 68.33 , while the mean of the employees who feel getting unfair treatment is 62.00 , with the level of confidence of $95 \%$. Despite the relative small comparison figures, in population these comparisons are significant enough to be used as consideration for decision making.

\section{Closing:-}

Through an analysis of Organizational Characteristics (F1), Environmental Characteristics (F2), Characteristics of Workers (F3), Characteristics of Policy and Management Practice (F4), and Policy Effectiveness of Resort Islands In Thousand Islands

Administrative District, it can be concluded that there are significant differences in each factor.

\section{Bibliography:-}

1. Abdul Wahab, Solihin. 2004. AnalisisKebijaksanaan, Jakarta: BumiAksara.

2. Arikunto, S. 2010. ProsedurPenelitianSuatuPendekatanPraktik (Revised Edition). Jakarta: RinekaCipta

3. Anderson. 1984. AnalisisKebijakanPublik. Yogyakarta: Gajah Mada University Press

4. Frederic in Agustino, Leo. 2008. Dasar-dasarKebijakanPublik. Bandung: Alfabeta

5. Ndraha. 2001. Efektivitas Perusahaan. Jakarta: BumiAksara

6. Ravianto. 1989. MengukurEfektivitasOrganisasi. Bandung: Alfabeta

7. Sedamayanti. 2001. EfektivitasOrganisasi. Jakarta: BumiAksara

8. Setyoko. 2008. EfektivitasOrganisasi. Jakarta: RajawaliPerss

9. Suharto, Edi. 2005. AnalisisKebijakanPublik: PanduanPraktisMengkajiMasalahdanKebijakanSosial. Bandung: Alfabeta.

10. Sugiyono. 2005. MetodePenelitianKualitatif. Bandung: Alfabeta.

11. Steers in Subarsono. 2005. AnalisisKebijakanPublik. Yogyakarta: PustakaPelajar. 